ĐORĐE ĆIRIĆ

94:634.8(497.11)"04/14"

Nova Pazova, Serbia

E-mail: djordjeciric1980@gmail.com
27-23-268

COBISS.SR-ID 272004108

Original research article

Received: October $13^{\text {th }} 2018$

Accepted: October $30^{\text {th }} 2018$

\title{
THE BIBLE AS A SOURCE OF INFORMATION ON MEDIEVAL WINEGROWING IN SERBIA
}

\begin{abstract}
Words from the Bible represent an inexhaustible source of information, either as symbolic and moral lessons or as technical descriptions of every-day life. It is precisely those technical data, read by farmers, and compared with other sources, that enable us to penetrate into the processes which affected grapevine and wine during the Middle Ages. Numerous verses from the Bible were directly cited in medieval codes of law, statute books and charters of the Serbian state. Aside from those, many descriptions and pieces of advice can also be read in these verses, whose application is confirmed by centuries-long practices in vineyards and wine cellars. Verses from the Bible contribute largely to the clarification of the manners in which winegrowers cultivated grapevine during the Middle Ages, and what effect it had on the plant itself, the wine, even the character of winegrowers which were tending vineyards and making wine.
\end{abstract}

\section{KEYWORDS: THE BIBLE, WINEGROWING, MIDDLE AGES, SERBIA, WRITTEN SOURCES.}

\section{INTRODUCTION}

The Bible $^{1}$ is a compilation of sacred texts written over a very long time span by numerous authors. Its reliability has often been contested, but in some cases also confirmed. Aside from that, the number of translations, as well as stylistic liberties taken by translators can prove to be a problem for an objective overview of the verses as sources of information. Undoubtedly, the symbolism in the verses of the Bible is significant and absolutely necessary for the understanding

1 As the principle source for verses, the translation of the Bible by the Institute for Hebrew language and literature in Belgrade was used for the Serbian language (Cвеmo писмо или Библија Старог и Новог завета, Institut za Hebrejski jezik iz Beograda). As additional sources, the Bible, the Old and the New Testament, Sinodal Text was used (Библия Книги Священного Писания Ветхого и Нового Завета, Синодальный Текст), as well as The King James Version of the Holy Bible. of it. However, as a relevant historical source for studying techniques of growing vine and making wine, it is necessary to take only the context of time and space as described by the authors of those verses, without attempting to shed a light on their moral teaching. The history of winegrowing, ${ }^{2}$ even though it is intertwined with different aspects of the human civilization, firmly depends on earth-related factors: the course of the nature and human actions. ${ }^{3}$ This is the reason why the authors of those verses who mentioned grapevine and wine also used their characteristics to make

2 Winegrowing is understood here as a term which comprehends the entire process, from planting the vine up to the placing of wine onto the table.

3 Phenophases of the growth of grapevine are under a direct influence of ecological factors, first and foremost - climate. On the other hand, the final quality of wine is affected by genetic aspects of the vine from which the grapes were picked and especially by the character of the winemaker who handled the process of wine making. 


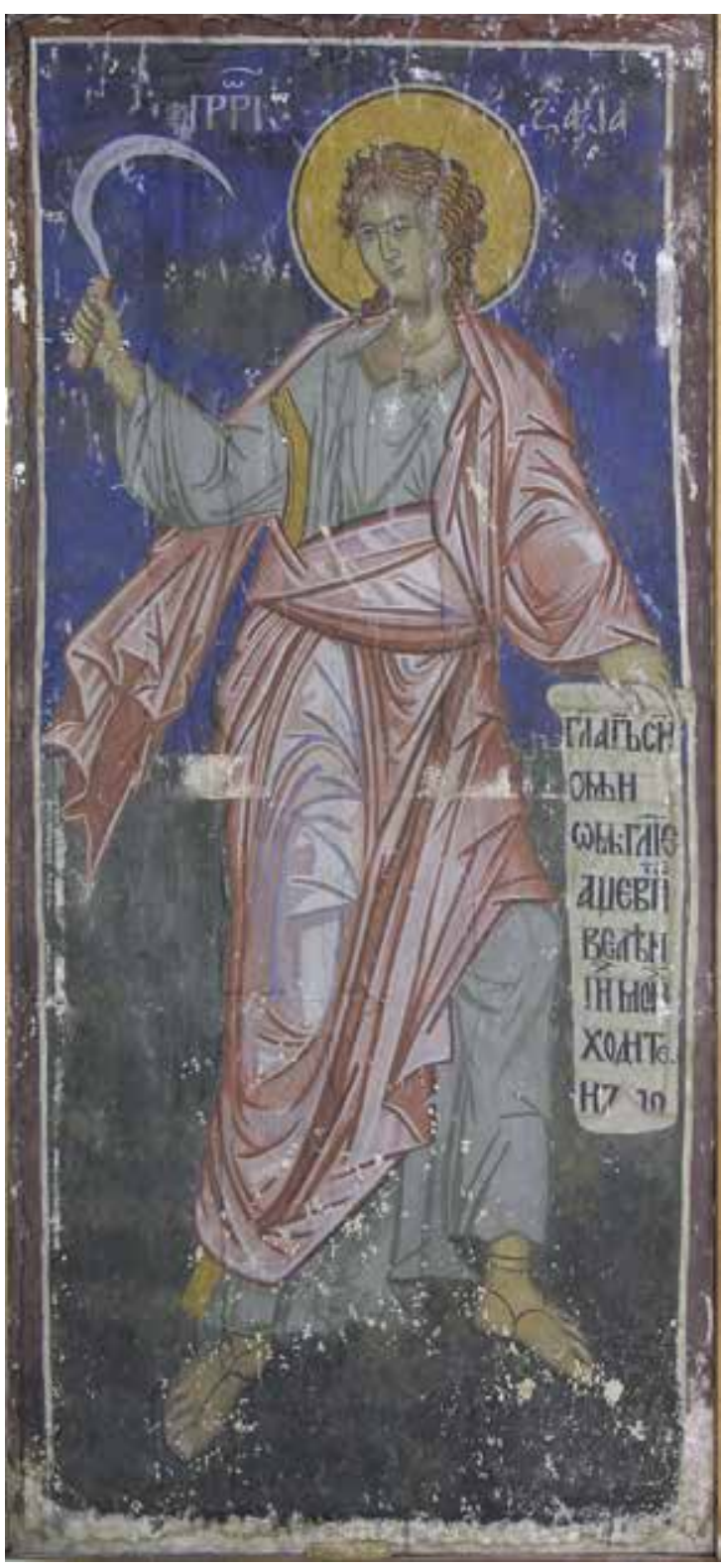

Fig. 1 Noah work vineyard. Fresco from monastery Decani. Gallery of frescoes, Belgrad.

comparisons with the human character and so on.

Moab hath been at ease from his youth, and he hath settled on his lees (Jeremiah 48:11).

Grapevine, wine, grapes and other terms directly or indirectly linked to winegrowing are mentioned in 43 out of a total of 72 books from the Old and the New Testament, in over 400 verses. ${ }^{4}$ Certain books are profuse and picturesque when it comes to the subject of grapevine growing

4 This difference is the consequence of different translations. techniques. The Book of the Prophet Isaiah lists all things that need to be done for the grapevine to bear grapes, what types of wine exist, which varieties are cultivated, what the consequences of inebriations are, etc. Others mention them solely in the context of moral lessons. The Bible abounds with information on grapevine and wine, and, aside from geographic determinants and, partially, ecological factors, ${ }^{5}$ those typical for the Near East, the areas of Judea and Israel, everything else can also be comparable with the area of the Serbian medieval state as well. Here, we mostly comprehend the social context which followed the development of winegrowing and agro-technical measures applied in vineyards and wine cellars.

In the beginning of the seventh decade of the $9^{\text {th }}$ century, Constantine, the elder of the missionary brothers, translated some the most essential liturgical books from Greek to Church Slavonic - a weekly Gospel, to be read during sermons (Aprakos), one legal text (Zakon sudny ljudem) and the most essential books of sermons for praying together (Hrvatska enicklopedija 2018). Serbian medieval winegrowers would have been, to a larger or smaller extent, familiar with the verses from the Bible. The easiest way that they would learn them would have been though clergymen and noblemen of lower ranks. Since the Church was the most omnipresent and probably the most organized structure in the Middle Ages, and the Bible essential for performing all liturgical services, it is beyond doubt that words it contained echoed far and wide. Therefore, recommendations from the Bible, both those concerning the spiritual life and those concerning every-day life, ranked high among role-models of proper living for a medieval man. As a proof for this, we may see that there are articles in medieval codes of law and statutes which sound as if they were copied directly from the verses of the Bible. Christian customs

5 Terrains suitable for growing vine along the Adriatic coast and most of the area of Southern Levant have similar climate conditions (temperature, precipitations, etc.). According to Kepen's classification, it is considered as Mediterranean, with hot summers (Csa). (M. C. Pell et al. 2007). 
of bestowing gifts and the sense of morality can be seen in the verse: When thou comest into thy neighbour's vineyard, then thou mayest eat grapes thy fill at thine own pleasure; but thou shalt not put [any] in thy vessel (Deuteronomy 23:24). To feed a traveller or a neighbour was quite natural, while stealing, on the other hand (taking more than needed) was considered unacceptable. This custom law found its place in numerous written stipulations of medieval Serbia. Byzantine agricultural law and its Serbian transcript completely agree with the essence of these verses, with one difference, in the enumeration of articles dealing with the subject. Article 58 from the Serbian transcription goes as follows: Those who enter into vineyards or fig-trees belonging to someone else, if they do so to eat, let them be innocent, and if they come to steal, let them be beaten while disrobed of their clothes (Благојевић 2007: 69). Verses from the Bible concerning the compensation of damages done to the grapevine were also included into the articles of this code of law: If a man shall cause a field or vineyard to be eaten, and shall put in his beast, and shall feed in another man's field; of the best of his own field, and of the best of his own vineyard, shall he make restitution (Exodus 22: 5). A similar disposition is found in Article 76 of Dušan's Code: If any man's cattle trespass on corn or a vineyard or a meadow in error, then let him pay for the damage done what the valuers assess. But if he let them trespass knowingly, let him pay for the damage done and also six oxen (Бубало 2010: 175). Charters of Serbian rulers also contain verses from the Bible. To name just one - the Chryssobull of King Dušan for the Monastery of Saint Nicholas of Myra in Orehovo. ${ }^{6}$ In the introduction, he cited a verse from Solomon's Proverbs - By me kings reign, and princes decree

6 The Chryssobull was written in 1339, and the Monastery of Saint Nicholas of Myra, with all its possessions and men, was thus gifted to the Monastery of Hilandar. Also, King Dušan exempted the settlements and people from the metochion of St. Nicholas of all works and taxes due to the Serbian Kingdom $c f$. Марјановић-Душанић 2003, 55.

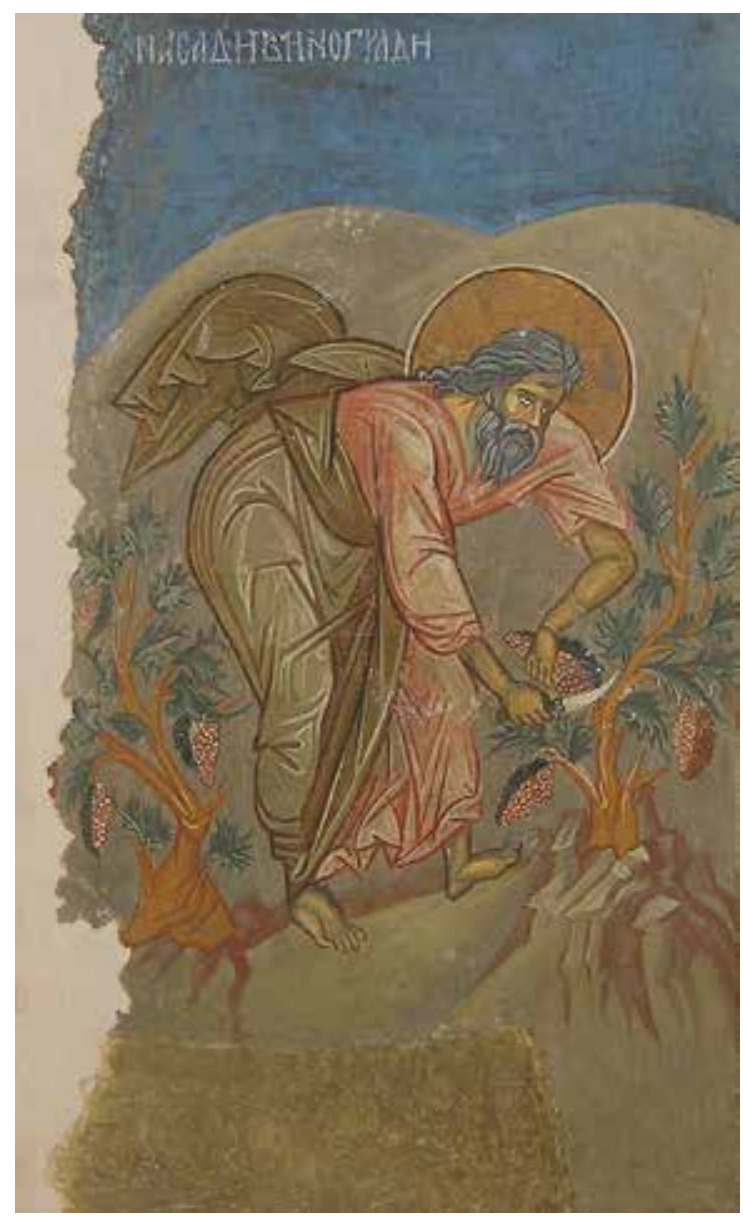

Fig. 1 Noah work vineyard. Fresco from monastery Decani. Gallery of frescoes, Belgrad.

justice $^{7}$ (Марјановић-Душанић 2003: 59). Out of a total of a dozen verses from Solomon's Proverbs dealing with winegrowing, we will single out verse 31:16: She considereth a field, and buyeth it: with the fruit of her hands she planteth a vineyard.

\section{SOCIO-ECONOMIC CONDITIONS}

Grapevine and wine, in a large number of cases, directly reflect historical events. They are often subjects of these occurrences, but protagonists as well. This link was recognized in the Bible. According to verses from it, the restoration of the human civilization began with the planting of vineyards. Verses from the Genesis ${ }^{8}$ state that, after the

7 Solomon's Proverbs 7:15.

8 Genesis, the First Book of Moses, is the first book in the 
water retreated, a sacrifice was made to God, who gave blessing to Noah and his descendants. Upon receiving this blessing, Noah planted a vineyard: And Noah began [to be] an husbandman, and he planted a vineyard (Genesis 9: 20). However, the very next verse talks of the dangers of inebriation: And he drank of the wine, and was drunken; and he was uncovered within his tent (Genesis 9: 21). The noxiousness of intemperate use of wine and other alcoholic beverages appears, as a warning, in numerous verses of the Old and the New Testament. The Book of the Prophet Isaiah speaks of the wrong decisions made by people who relied more on men than on God, which lead to the fall of the Israelites into Babylonian captivity. One of the culprits for those bad decisions was immoderate wine consumption: But they also have erred through wine, and through strong drink are out of the way; the priest and the prophet have erred through strong drink, they are swallowed up of wine, they are out of the way through strong drink; they err in vision, they stumble [in] judgment (Isaiah 28: 7). And again, similarly, in this verse: Woe unto [them that are] mighty to drink wine, and men of strength to mingle strong drink (Isaiah 5: 22). Alcoholism, i.e. immoderate consumption of wine, mead and beer continued to be a great problem during the Middle Ages as well. Sources tell us that the Slavs had the custom of using wine, instead of torture, to uncover secrets (Орбин 1968: 151). An event which occurred in the autumn of 1342 confirms the existence of a problem. In his book Istorija Srba (The History of Serbs), Ćorović wrote that, during the military campaign of the Serbian state and the Byzantine emperor Kantakousenos against the city of Serres, Serbian soldiers drank, too eagerly, new wine, which they weren't used to, hence, as many as 1.500 of them got sick with dysentery, ${ }^{9}$ and they were thus rendered use-

Christian Bible and the Hebraic Tanakh. It is the story of the creation of the world.

9 Dysentery can easily be caused by consuming large amounts of must, which hadn't finished fermenting and turning sugars into alcohol. Because of the high percentage of sugar in it, must can get spoiled and microorganisms less without any actions from the enemy. Being familiar with this problem, from their experience, Serbian rulers placed stipulations in their laws to try and prevent this damaging social occurrence (Ćorović 2001). Article 166 of Dušan's Code says: If a drunken man come from anywhere and strike anyone or cut him or wound him, yet not to death, then shall one eye be removed and one hand cut off. But if a drunken man molest anyone or pull off his cap or do him other insult, but do not wound him, he shall be flogged with one hundred strokes and cast into prison, and when he is taken from prison he shall be flogged again and released (Бубало 2010: 213).

Grapevine and wine were also mentioned in contexts of consequences or warnings of imminent events. The element of action and reaction doesn't refer only to the consequences of inebriation. God rewards correct actions with abundance of grapevine and wine, and punishes evil actions with their absence. It is through the Prophet Amos that God warns the people of Israel: Forasmuch therefore as your treading [is] upon the poor, and ye take from him burdens of wheat: ye have built houses of hewn stone, but ye shall not dwell in them; ye have planted pleasant vineyards, but ye shall not drink wine of them (Amos 5: 11). On the other hand, at the gathering at Shechem, the one true God addresses the united tribes of Israelites: And I have given you a land for which ye did not labour, and cities which ye built not, and ye dwell in them; of the vineyards and oliveyards which ye planted not do ye eat (Joshua 24:13). With these words, the alliance is fortified between the tribes of Israel and Yahweh (the one true God), who fought on their side and enabled them to conquer Israel, under the leadership of Joshua. The Serbian people found themselves in a similar historical situation during the reign of King Milutin (1282-1321) and the conquering of winegrowing areas in the valley of Vardar, Gornji and Donji Polog and Pijanec. However, during the $16^{\text {th }}$ and the $17^{\text {th }}$ century, after large migrations of the Serbian population from the arcan develop in it, which could, in turn, cause dysentery. 
eas of Macedonia and Kosovo into the Pannonian valley, the art of winegrowing in these areas began to dwindle. Let us conclude this topic with verses: Who goeth a warfare any time at his own charges? who planteth a vineyard, and eateth not of the fruit thereof? or who feedeth a flock, and eateth not of the milk of the flock? (1 Corinthians 9: 7).

An important evidence of the value - and not just symbolic value - of grapevine and its fruit, grapes and wine, in the Bible, is provided by a verse from the Gospel of Matthew: Woe unto you, scribes and Pharisees, hypocrites! for ye pay tithe of mint and anise and cummin, and have omitted the weightier [matters] ${ }^{10}$ of the law, judgment, mercy, and faith: these ought ye to have done, and not to leave the other undone (Matthew 13: 23). A tenth portion of agricultural produce and such, called tithe (desetina - "tenth part"), was the usual tribute given by subordinate population during the period of the Serbian medieval state. Wine was intensely consumed during the Middle Ages, hence, it was very convenient for being taxed. Wine taxes were the main fiscal income of Serbian cities along the Adriatic coast. In Kotor, though, it wasn't $1 / 10$ of the price but $1 / 16$ of the value of wine, however, with the obligatory surtax - it was higher than the usual tithe. The Statute of Kotor, in Article 389, speaks of those special taxes: patroni vini solvant sextam decimam pertem vini, videlicet quantum dant doane, ad dictum laborerium, incipiendo die primo septembris (Čremošnik 1933: 29). In accordance with the value of wine, Serbian rulers absolved, as a form of economic protectionism, people from monasteries and metochia of various forms of tributes and obligations linked to grapevine and wine. In Article 34 of his Code, Emperor Dušan exempted people of the church of work obligations in manorial and imperial vineyards: $U$ што соү села ирьковна и людїє црьковныи, да не

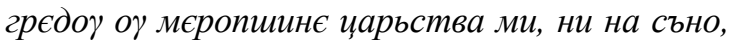
ни на юранїє, ни на виноградь (Бубало 2010: 82).

10 In the Serbian translation, these verses were thus translated: Woe unto the literates and Pharisees, who pay tithe of dill and pomegranate, while robbing and omitting to give grapes, which have a higher price...
Grapes and wine have represented, ever since the Antiquity, a source of economic prosperity. Vineyards were objects of valuable gifts and also trade, buying, selling, exchanging, leasing. We learn this from The First Book of Kings: Because I spake unto Naboth the Jezreelite, and said unto him, Give me thy vineyard for money; or else, if it please thee, I will give thee [another] vineyard for it (1 Kings 21 : 6 ). The fact that the yield of grapevine represented a fundamental nourishment in every-day life made it more important than its economic value. The first words of blessing that Isaac gave to his son Jacob: Therefore God give thee of the dew of heaven, and the fatness of the earth, and plenty of corn and wine (Genesis 27: 28). Wine, or, in this case, must ${ }^{11}$, goes hand in hand with corn - bread. There are many reasons for that. It suffices to mention only the hygienic value of red wine, which, during the Middle Ages, often represented, in terms of health, a safer beverage than water, especially in city centres. ${ }^{12}$

Thus, confirming what was said in our previous passage, vineyards were traded with, they were given as presents and lease contracts were signed in the Serbian medieval state. Among the numerous vineyards gifted by rulers to their foundations, there were also vineyards bought from the small people. Thus, Prince Lazar listed among gifts to his foundation Ravanica, along the vineyards he inherited and planted himself, two which were bought from Crep and Jugda (Новаковић 1912: 769). Lease was a common manner of managing vineyards along the Adriatic coast. We have information on this from numerous contracts, but also articles of statutes of cities along the Adriatic which regulated the rights and obligations of lessees and owners of vineyards. In the Statute of Budva ${ }^{13}$, as many as five chapters

11 In some verses of the Bible, new wine can be considered as actual new wine, with recently finished fermentation and removed from lees. In other cases, it seems more likely to be must, where we can explain the epithet of "new" as not yet fermented into wine, which can cause drunkenness.

12 The wine is free from pathogens which may have been present in the water. Also, its acidity and alcohol in it kill many of the pathogens which can contaminate water and cause diseases.

13 A fundamental document which arranged every-day 
were dedicated to this subject, almost all of them dealing with norms regarding vineyards. Chapter 36, On lease, clearly stipulates: We order that he who takes under lease for a certain price a vineyard, field, house or other, is duty bound to work well and finish the works in time, according to the contract (Средњовековни статут Будве 1988: 23). On the importance of wine in the alimentation of the population, we have an exhaustive article from the Law of Novo Brdo ( $\omega$ тргү рүпнемъ): $:^{14}$ For as long as the wreath, placed by the Prince onto the square, shall stand, the common folk shan't buy flour and wine and other things until the miners (rupnici) have provided for themselves on Sundays before eating (Радојичић 1962: 53). Miners were a highly valued class, whose productivity was directly linked to the scope of the wealth of Serbian medieval rulers. This is the reason they had priority in procuring basic food. Flour and wine go hand in hand, as the basis of alimentation of medieval men.

Two factors are listed in the Bible as directly responsible for the beginning and further development of winegrowing in a certain area. They are both significant for almost every sphere of human actions, but the first one to suffer because of their absence are precisely grapevine and wine quality. The first one is a stable social situation; no wars, natural disasters, epidemics or great migrations of the population. Even the increase of life standard is a desirable factor for successful cultivation of grapevine and wine. The second historical circumstance which aids the development of this activity is independence, freedom of the people and the territory they live on and practice the activity of winegrowing. Winegrowing is a sphere of human actions which demands that a large number

life in the city municipality of Budva during the Middle Ages. It was most probably written in the middle of the $14^{\text {th }}$ century, during the reign of Emperor Dušan, even though many of its stipulations were being applied long before that.

14 The Law of Novo Brdo regulated every-day life at Novo Brdo, the most important mining settlement on the Balkans. It is an integral part of the Law on mines by Despot Stefan Lazarević. It was published on January the $29^{\text {th }}$ 1412. $C f$. Радојичић 1962. of people takes part in it during most of the year, both for the tending of vineyards and also for consuming the products from those vineyards. This was recognized by the Bible in verses: When I shall have gathered the house of Israel from the people among whom they are scattered, and shall be sanctified in them in the sight of the heathen, then shall they dwell in their land that I have given to my servant Jacob. And they shall dwell safely therein, and shall build houses, and plant vineyards; yea, they shall dwell with confidence, when I have executed judgments upon all those that despise them round about them; and they shall know that I [am] the LORD their God. (Ezekil 28: 25, 28: 26). In this fierce speech against the heathens, the one true God promises peace and prosperity to the Israelites, symbolized with the building of homes and planting of vineyards. But even before a foundation of home, the people could estimate, on the basis of prosperity of grapevine, the level of wellbeing of an area. Here's what Moses had to say on the subject: ... whether there be wood therein, or not. And be ye of good courage, and bring of the fruit of the land." Now the time [was] the time of the first ripe grapes (Numbers 13:20). And later: And they came unto the brook of Eshcol, and cut down from thence a branch with one cluster of grapes, and they bare it between two upon a staff; and [they brought] of the pomegranates, and of the figs (Numbers 13: 23). The oversized clusters born by Moses' scouts from The Promised Land symbolize the fertility of the valley of Eshcol. A beautiful depiction of these verses can be seen in the Igumenaria ${ }^{15}$ of the Monastery of Hilandar on Mount Athos.

Success in cultivation of grapevine, spreading of vineyards, and intensity of production and especially consumption of wine can be directly linked to state-building processes of a given people as well. Planting vineyards and making wine in medieval Serbia was followed, hand in hand, by its

15 Igumenaria is an object within the Monastery of Hilandar, ranging from the dining chamber built by King Milutin all the way to the great dormitory on the northwestern side of the monastery. Its name is due to the fact that hegumens (iguman) lived in it. 
territorial, economic and demographic development. On top of that, the amount of wine present in the alimentation and trade provides a direct reference on the level of life standards and cultural development of a given group of people. The peak of many aspects of medieval Serbia can be found at the Monastery of Dečani, built by two members of the Nemanjić dynasty, ${ }^{16}$ and whose architecture and fresco-paintings are extremely important for the world cultural heritage. ${ }^{17}$ The iconostasis and architectural decorations of the Monastery of Dečani abound in depictions of every-day life and represent a rich source of data on life in Serbia during the $14^{\text {th }}$ century. One important part of those motifs are also those with grapevine, which show the indubitable importance it had in the Serbian medieval state. During the Middle Ages, wine represented a valuable nutriment, worth the trouble of organizing the risky trade by caravans. Bearing witness of intense wine trade, we have numerous contracts and articles from statute books of various cities (Čremošnik 1933: 31). For example, the laws of Kotor forbade its citizens to sell any wine aside from that of Kotor in the area between Budva and Molunat. Wine was transported in special wooden barrels (vozilnica) and wineskins, especially those made of goat skin (Јиречек 1978: 169). The Bible doesn't mention wooden barrels, but wineskins and ceramic vessels (pitchers) were frequent means for transporting and storing wine. [O]ne carrying three kids, and another carrying three loaves of bread, and another carrying a bottle of wine (1 Samuel 10: 3). Wineskins were made of leather obtained from different animals ${ }^{18}$ and they had different use val-

16 It was built in the period from 1327 up to 1335 . The original founder was King Stefan Dečanski (1322-1331), and it was during the reign of his son Dušan (1331-1355) that the building was finished.

17 Since 2004, the Monastery of Dečani is included in the UNESCO list. The explanation states that the architecture of the monastery and its paintings represent an extraordinary combination of the eastern Byzantine and western Roman tradition.

18 The Bible mentions sheep, goats, especially kids, cattle. Therefore, their skin represented materials out of ue and quality. They were used over long spans of time, hence, they were often mended: and took old sacks upon their asses, and wine bottles ${ }^{19}$, old, and rent, and bound up (Joshua 9: 4).

The ascending trajectory of Serbian winegrowing can be traced through charters, creating an almost unbroken ascending line all the way until the fall of Smederevo in the middle of the $15^{\text {th }}$ century. From the first charters, made in the end of the $12^{\text {th }}$ century, where vineyards were seldom mentioned, all the way to those from the period of the Serbian Empire and Despotate, when they were so widely diffused that they represented borders and prominent spots in village counties, named after the people tending them or their proprietors, etc. Since the time of the founder of the Nemanjić dynasty, Stefan Nemanja, winegrowing was a direct reflection of the economic power of the ruler and the state. In the end of the $12^{\text {th }}$ century, he gave Hilandar the gift of nine villages in the vicinity of Prizren, stressing that he planted two vineyards there as well: $И$ два винограда тоуиге насадихь... (Новаковић 1912: 384). One century later, vineyards were so numerous that they were actually a border. His descendant Milutin was one of the most powerful Serbian rulers of the Middle Ages. He displayed his and Serbia's economic power in the Saint Stephen Chryssobull (1314-16). The founding charter of his foundation - the Monastery of Banjska depicts the highly developed level of winegrowing in several aspects. The Monastery of Banjska had had, from the very foundation, a very large metochion. It incorporated 75 villages and hamlets. In a detailed description of its lands, vineyards were also listed. For example, the village of Gumno in Hvostno ${ }^{20}$ had for a border, among other things, the vineyard of a certain Georgije: And in Hvostno the village of Gumnište, with borders [...] and on the ridge which leads from Plužine, on the opposite side from the vineyard of Georgije, into the same

which wineskins for wine transport were made. It was a similar case in medieval Serbia.

19 In the Serbian translation, instead of the word bottle, word wineskin is used.

20 The area of today's Northern Metohija. 
Bojatja pear [trees] (Ковачевић 1890: 3). Large surfaces planted with grapevine induced Milutin to impose the obligation onto his depending subjects of hoeing the vineyards of monasteries. At the peak of the Serbian medieval state, in the middle of the $14^{\text {th }}$ century, the founding charter of the Monastery of the Holy Archangels was written. The economic power of the metochion of this monastery was accompanied by extremely complex activities in winegrowing. In order to meet the needs of this monastery, land consolidation was performed in the area of Prizren, by which the vineyards of the monastery were augmented through exchange with the local population: And these are the vineyards of this church (Rajkova crkva): the vineyard at Kruševo polje, was taken in exchange from Nježa; and the vineyard in Babiste, and the vineyard in Pustice, they were both taken in exchange from Nježa for those at Kurilo. The vineyard behind the courts, and we took it in exchange from Dabiživ the usurer for that at Kurilo; the vineyard at Gabrovci, and we took it in exchange from Bojko for that at Kurilo; and another vineyards behind the courts, and we took it in exchange from Dabiživ the usurer for that at Kurilo; the vineyard at Gabrovci, and we took it in exchange from Odeljan, for that at $\mathrm{Ku}$ rilovo; and in Pustice two vineyards, and we took it in exchange from Ivanko the weaver for that at Kurilovo; the vineyard in Lipovci, and we took it in exchange from Dmitar for that at Kurilovo; the vineyard at Hinatovci, and another in Dubrovice; the vineyard above Puljša; the vineyard at Drenovci; the vineyard at Babišta; the vineyard at Pustice, and Rajko's field between the waterworks, below Đurovište, up to the walnuts; and other fields below from the waterworks, two parts in the same place (Новаковић 1912: 684, 685). We can see from the charter that a dozen vineyards, which were the property of people from Rajkova crkva, and in the immediate vicinity of Prizren, had been exchanged for vineyards at Kurilo. It seems that from the fertile vineyards of Kurilo exquisite vintages arrived. In order to perform land consolidation in a proper manner, vineyards going into exchange have to have similar health status, fertility potential, even grapes (varieties) of similar quality. Augmenting the property (vineyards) enabled easier cultivation of grapevine and larger influence on the quality of wine, which would end up in the imperial wine cellars of the city of Prizren.

The same bound between the development of winegrowing and state-building can be seen in the verses from the Book of the Prophet Jeremiah: Ye shall drink no wine, [neither] ye, nor your sons for ever: Neither shall ye build house, nor sow seed, nor plant vineyard, nor have [any:] but all your days ye shall dwell in tents; that ye may live many days in the land where ye [be] strangers (Jeremiah 35: 7). The subject of those verses is the fall of the state of Israelites into Babylonian captivity. They lost their homeland, thus, as apatrides, they couldn't build a future in a foreign land. Building a house, making a home, sowing the seeds of grain to obtain flour and planting vineyards; all in the same context of permanent settlement in a specific area. Vineyards are planted for the period of at least half a century ${ }^{21}$ and always for the descendants. They can be maintained on the same spot, propagating either spontaneously, from seeds, or with the help of men, through layering, and they can bear fruit for several centuries (Blagojević 2004: 114). One vineyard in the vicinity of Peć, given by Stefan Prvovenčani to Hilandar, can be traced in written sources for at least 250 years. Even Solomon, the personality which is the symbol of wise actions in many traditions, says: I made me great works; I builded me houses; I planted me vineyards (Ecclesiastes 2: 4). Judging by their actions, this was also a notion which guided the rulers of Serbian lands

21 A foundation of Emperor Dušan, the Monastery of the Holy Archangels Michael and Gabriel had a very imposing metochion, one in accordance with the founder. Four churches which were placed under the primacy of the Monastery of the Holy Archangels owned vineyards in the farther or imminent vicinity of Prizren. Also, new vineyards were planted for the needs of this Monastery. Judging by these data, vineyards, and probably the number of monks of the Monastery of the Holy Archangels were quite large. This is additionally confirmed by the fact that monks were forbidden to venture into wine selling, hence, probably all of the monastery wine ended up on the tables of the monks. 
during the Middle Ages. The increasing amount of surfaces covered with grapevine directly reflected the increase of the territory of the state, not only through mere appropriation of the existing ones, but also through planting new ones. Therefore, as a permanent mark of state-building and identity as a whole, vineyards were planted near monasteries, on their properties.

\section{CULTIVATION OF VINEYARDS}

The Bible provides numerous descriptions of winegrowing practices. They are sufficiently realistic to provide proof beyond doubt that authors of those verses had models for them in every-day life, and never more so than in the Book of the Prophet Isaiah. ${ }^{22}$ The introductory verses explicitly state that vineyards are planted on fertile hills: Now will I sing to my wellbeloved a song of my beloved touching his vineyard. My wellbeloved hath a vineyard in a very fruitful hill (Isaiah 5: 1). We can also judge this practice of planting vineyards on hills by a Roman proverb that Bacchus loves hills - Bacchus amate coles. Certainly, grapevine has been planted, up to today, on terrains with almost every exposition and inclination, but mildly steep sides of sunny hills remain the symbol of quality, as shown by the verse: Thou shalt yet plant vines upon the mountains of Samaria (Jeremiah 31: 5). It was the same case with vine-growing terrains of medieval Serbia as well. The famous medieval vine-growing areas (stupovi) ${ }^{23}$ of Preradovac in Levča, Senjani near Orahovac, Kurilo, uphill from Prizren, and others, they were all located on mild hill slopes. The following verses from the Book of the Prophet Isaiah provide us with plen-

22 Depending on the manner of propagation, grapevine reaches full fertility potential around year five, and, depending on how well they were tended, can be productive for over 100 years.

23 This Book speaks of the life of the Prophet Isaiah, who lived in the end of the $8^{\text {th }}$ century BC. The story takes place in the Kingdom of Judah, an area which comprehended the central part of today's Israel, between the Dead and the Mediterranean Sea. ty of information on activities that a winegrower had to perform in order to have an abundant and high-quality harvest, and, on the other hand, what occurs should he fail to do them in due time and in the correct manner: And he fenced it, and gathered out the stones thereof, and planted it with the choicest vine, and built a tower in the midst of it, and also made a winepress therein: and he looked that it should bring forth grapes, and it brought forth wild grapes (Isaiah 5: 2). What could have been done more to my vineyard, that I have not done in it? wherefore, when I looked that it should bring forth grapes, brought it forth wild grapes? (Isaiah 5: 4). The revolted winegrower makes a promise then: And now go to; I will tell you what I will do to my vineyard: I will take away the hedge thereof, and it shall be eaten up; [and] break down the wall thereof, and it shall be trodden down (Isaiah 5: 5). And I will lay it waste: it shall not be pruned, nor digged; but there shall come up briers and thorns: ${ }^{24}$ I will also command the clouds that they rain no rain upon it (Isaiah 5: 6).

A pictorial description of those verses by Isaiah can be seen on the iconostasis at the Monastery of Dečani. On the fresco-painting named Noah cultivates his vineyard, the icon painter of the Monastery of Dečani Grešni Srđ (Ковијанић 1962: 36-37) gave a faithful description of the practice described in the Bible. The central plan of the icons shows Noah with a vineyard knife, picking large reddish clusters. The grapevine is growing from stones on mild hill slopes. Also, it provides a clear depiction of the manner of forming a grapevine trunk in medieval vineyards. There are canes growing directly from the trunk, three on each vine. Indirectly agreeing with this depiction of the manner of cultivation, we have these verses: And in the vine [were] three branches: ${ }^{25}$ and it [was] as though it

24 Stup is a section of land covered with grapevine or another horticultural crop, which differs from the neighbouring ones by a certain quality they possess.

25 King James Bible specifically lists briers (Rosa canina), while the Serbian translation only mentions weeds. Brier rose is very well known in these areas, and its fruit is highly valued, by the name of rosehip. 
budded, [and] her blossoms shot forth; and the clusters thereof brought forth ripe grapes (Genesis 40: 9, 40: 10). It is said that all three branches are in bloom and bearing fruit. The appearance of the vine from the fresco-painting and the description from the verses irresistibly remind us of a very old and widely spread manner of shaping vine trunks. It is known under many names, and almost all populations which cultivate grapevine know it and practice it. In France it is called goblet (gobellet), in Italy - little tree (alberello), and in Spain simply - vineyard (viñedo). Winegrowers from Serbia know it under the name of "župski" method of cultivation. It is modelled on a short trunk with three or several more canes which form a goblet-shaped crown. During the Middle Ages, vineyards with short trunks were called "lozije" in Serbia, thus denoting a clear difference in respect to those formed on a trellis or a different kind of canopy (Благојевић 2004: 116). The difference is not based merely on the visual aspect. Depending on the height and heaviness of the fruit and vegetative parts of the grapevine, it will bear grapes, and afterwards provide wine, of different quality.

In the verses of the Bible, vineyards are pruned and hoed without fail, as in the already quoted verses from the Book of the Prophet Isaiah. These basic agro-technical measures of winegrowing were unavoidable in vineyards of medieval Serbia as well. They are mentioned as fundamental in Article 11 of the Serbian translation of the Agricultur-

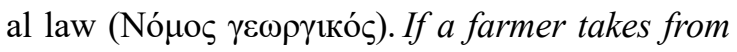
an impoverished farmer a vineyard to work on it, under lease, and doesn't prune it properly, doesn't provide shade, and doesn't put on poles, and fails to hoe it twice, he shall receive none of the fruit (Благојевић 2007: 55). The vineyard had to be tended in a proper manner or the lessee of that vineyard would lose the right to the yields from it. The description of obligation lists agro-technical measures which a medieval winegrower was to apply, even under obligation, if necessary. It is interesting to note that the adverb "properly" was mentioned when it came to pruning, thus implying that this operation required a certain level of expertise. Pruning is a fundamental operation in the cultivation of grapevine. It is, in fact, so important, that we cannot speak of true vineyard cultivation or beginnings of winegrowing until some sort of vine pruning started to be applied on a regular basis. A historical example of this can be found at the Apennine peninsula during the clash of two cultures - Etruscan and Roman. On the basis of written data, confirmed by analyses of grapevine seeds, it was established that the Etruscans hadn't practiced pruning until the Romans, who were instructed by the Greeks and the Phoenicians, introduced this practice as fundamental in their vineyards. The difference between these two practices can be noted since the $3^{\text {rd }}$ century BC. Pruned vine has larger seeds and berries, which provide grapes and wine of higher quality (Aversano et al. 2017: 11). The Bible forbids the eating of grapes from an unpruned vine: neither gather the grapes of thy vine undressed (Leviticus 25: 5). Similarly to this, the Romans forbade that wine be served during their feasts which was made of grapes from unpruned vines (Toussaint-Samat 2009: 243). Pruning provides larger grapes of higher quality, prolongs the life cycle and condition of the vine and enables many other good aspects, as proven by practice during the fellowship of men with this noble plant. In order to perform the pruning in a proper manner, certain tools are necessary. Tools for pruning canes of grapevine and picking grapes mentioned in the Bible are knives and sickles: For afore the harvest, when the bud is perfect, and the sour grape is ripening in the flower, he shall both cut off the sprigs with pruning hooks, and take away [and] cut down the branches (Jeremiah 18: 5); and also: Thrust in thy sharp sickle, and gather the clusters of the vine of the earth; for her grapes are fully ripe (Revelation 14: 18). And, indeed, the vineyards of medieval Serbia were pruned and grapes from them harvested with vineyard knives or billhooks. When it came to vines with low trunks, pruning resembled mowing (Ћирић 2017: 48).

The second fundamental operation in tending 
vineyards is working on the land. Hoeing around vines is important for multiple reasons concerning the tending of grapevine. Winegrowers came to realise this very early on. Justinian's Code, in Article 14, demands that winegrowers "dig through and grub" their vineyards (Благојевић 2007: 99). Pruning and grubbing the soil ${ }^{26}$ maintains the humidity, looseness, and favourable air conditions. A fact especially stressed by authors from the Antiquity ${ }^{27}$ is that frequent hoeing and grubbing, in due time, eliminates weed and thorns, here probably comprehending, amongst others, dewberry (Rubus caesius) and similar plants from the bedstraw family (Rubaceae sp.). Even today, they are very invasive in places where vineyards were planted. The verse: And I will lay it waste: it shall not be pruned, nor digged; but there shall come up briers and thorns: I will also command the clouds that they rain no rain upon it (Isaiah 5: 6) says enough on the antagonism between grapevine and its weedy enemies, especially thorn bushes. The importance of pruning in due time was also stressed by numerous articles from Serbian medieval laws, statutes and charters. One of the most extreme examples can be found in the Saint Stephen Chryssobull ${ }^{28}$ by King Milutin. The founding charter of the Monastery of Banjska is extreme because of the punishment it provides for those under work obligation who should fail to hoe a section of the monastery vineyard before Easter. And everyone must hoe the vineyard, both priest and neophyte and peasant, and also master builders and all other workers. He who doesn't hoe it until Easter, an ox shall be taken from him (Новаковић 1912: 625).

26 The technical term for a new branch - a one-year-old extension between nodes - is actually canes, but we won't hold it against the author of these beautiful verses.

27 The Agricultural law was also known as the Slav law, since it combined articles from Justinian's Code and custom laws of the Slavs. This fundamental document regulated obligations in villages and agrarian production. It is assumed that it was in use since the Serbian conquest of Byzantine territories in Macedonia, in the period of reign of King Milutin. C $f$. Благојевић 2007.

28 The term is used here to describe shallow digging, performed with the goal of breaking the hard thin layer covering the surface of the soil.
Ahab said to Naboth: Give me thy vineyard, that I may have it for a garden of herbs (1 Kings 21: 2). Forming a garden along with grapevine, as well as intercropping ${ }^{29}$ was not a rare occurrence in medieval vineyards. This practice originates from the Antiquity, as confirmed by numerous Antique authors. Bertius wrote that it was best not to sow anything in a vineyard, but that he knew, from practice, that winegrowers planted vetches, squashes and cucumbers (Geoponika 1805: 154). The Bible even provides a technical measure which regulates the application of intercropping in vineyards, that is to say, it forbids that more than two types of seed be sown in a vineyard. Thou shalt not sow thy vineyard with divers seeds: lest the fruit of thy seed which thou hast sown, and the fruit of thy vineyard, be defiled (Deuteronomy 22: 9). Seed propagation shows us that agricultural or, more often, vegetable crops were used for intercropping in vineyards. Intercropping was common in vineyards of medieval Serbia as well. They enabled the husbandmen to have additional income and softened the economic loss created through long periods of waiting for the vineyard to reach the period of optimal fertility. In the area of the Adriatic, plants from the gourd family were often planted along grapevine, while sharing the same fate. Jiriček wrote that in 1336 the prior of the Monastery of Saint Jacob near Dubrovnik pressed charges against two neighbouring noblemen, Milten and Ruđer, who sacked the vineyard and orchard of the Monastery, especially the gourd garden with muskmelons, with their horseman (Јиречек 1978: 286).

Cui rei maxime videtur esse idonea opulus: ea est arbor corno similis (Columella 1745: 235) Columella's description of red guilder rose (Viburnum opulus), which he considered to be the ideal species for supporting the dense growth of grapevine canes. Ever since the Antiquity, grapevine has been cultivated along the trunks of different trees, often fruit, which provide support for it or

29 One of the examples is a recommendation by Columella not to impose limitations on the number of times the soil is hoed, and that the only limitation should be the price for performing this operation. $C f$. Columella 1745: 166. 
simply grow along with them in some sort of orchard-vineyard, thus creating a specific agro-ecological unit. In the Song of Songs, the protagonists of the verses go into the vineyard to see if the vine has begun to flourish and pomegranate bloom: Let us get up early to the vineyards; let us see if the vine flourish, [whether] the tender grape appear, [and] the pomegranates bud forth (Song of Songs 7: 12). Pomegranate (Punica granatum) is a beautiful ornament of Mediterranean gardens and orchards typical for the Levant, which do not succeed very well in the humid continental climate. In continental parts of medieval Serbia, grapevine wasn't growing along pomegranate bushes, but rather in the company of apples, pears, cherries. According to Blagojević, we learn from the Practicum of Hilandar about the grapevine which grew in an orchard with the surface of one cable and a half: ... лозиєе второ садьно сь швоштилємь кьблӨ и поль... (Благојевић 2004: 116).

During the Middle Ages, vineyards were often fenced. A fence around a vineyard was, in fact, a necessary agro-technical measure, regulated by law, in medieval Serbia. Article 55 (among others) of the Serbian transcript of the Agricultural law warned that: He who sets the fence of a vineyard on fire, is to be beaten and his hand branded, but also has to compensate for the damage by twofold (Благојевић 2007: 67). Aside from wooden fences, vines and their valuable fruits were protected from unprincipled people and hungry animals by raising stone walls, digging trenches, setting up legholds and other traps, and even by raising towers (pirg) in vineyards. Stone walls - drywalls (suvomeđina) were frequent means of protection of vineyards in verses of the Bible: But the angel of the LORD stood in a path of the vineyards, a wall [being] on this side, and a wall on that side (Numbers 22: 24). ${ }^{30}$ Drywalls were widely diffused in vineyards of medieval Serbia as well, especially along the

30 This charter of King Milutin was written after he finished building his sepulchral foundation, in the middle of the first decade of the $14^{\text {th }}$ century. It lists in detail all properties given to the Monastery of Banjska and the obligation of the serfs towards it. Cf. Новаковић 1912: 623.
Adriatic coast, which has similar ecological conditions (climate and soil type), but also the dominant raw material (stone) for making fences as that near the Dead Sea, where the events from the verses of Moses take place. Verses from the Proverbs of Solomon tell us how the vineyard of a lazy man is covered with nettles, and the wall of the vineyard collapsed, directly linking successful tending of the vineyard with fences: I went by the field of the slothful, and by the vineyard of the man void of understanding; And, look, it was all grown over with thorns, [and] nettles had covered the face thereof, and the stone wall thereof was broken down (Proverbs 24: 30, 24: 31). Towers in monastery vineyards at Mount Athos are not a rare occurrence, e.g. the tower of King Milutin ${ }^{31}$ in the vineyards of the Monastery of Hilandar. Watchtowers were built as the final line of defence and refuge in tumultuous times of the Middle Ages, and their building in vineyards can be understood in two manners. One speaks of the value of grapevine per se, and the other of the position of vineyards on the properties owned by monasteries, since they were often built on inaccessible places, where other agricultural crops couldn't have been cultivated with success.

The Bible also abounds in descriptions of the climate which is favourable for the cultivation of grapevine. Successful cultivation of grapevine requires humidity. Therefore, God promises true believers that they will have rain in due time: Then I will give you rain in due season, and the land shall yield her increase, and the trees of the field shall yield their fruit (Leviticus 26: 4). Verses which compare peacefulness with ideal climate conditions during the time of harvest are especially interesting: For so the LORD said unto me, I will take my rest, and I will consider in my dwelling place like a clear heat upon herbs, [and] like a cloud of dew in the heat of harvest (Isaiah 18: 4). Morning dew is one of the representative traits for the quality of fruit and grapes. It is created when cold nights

\footnotetext{
31 Intercropping is a practice in which additional plants are planted in-between the rows of the basic plants which are being cultivated, most commonly fruit and grapevine.
} 
and warm days alternate, most commonly in late summer and early autumn, i.e. in the period when grapes are harvested. This alternations provide that metabolism products, created in fruit during warm days, and large accumulation of sugar and other elements of quality remain preserved in fruit through diminished activity (breathing) during cold nights. ${ }^{32}$

In every consideration of the potentials of a winegrowing area, the starting point are always the dominant varieties in vineyards of that climate. Even though it's not very likely that varieties described in the verses of the Bible found their place in vineyards of medieval Serbia, it isn't entirely impossible. During the Middle Ages, there was a dynamic flow of people and goods between different areas of Europe, Northern Africa and Near East. Thus, for example, numerous pilgrims who went to the Holy Land, merchants, diplomatic missions, and even soldiers of the Crusades, could have easily taken with them canes ${ }^{33}$ from the Near East into their own homelands. We don't know the exact names of varieties from the Bible, but there are wonderful descriptions of them. The Book of the Prophet Isaiah favours the variety with intense red colour of canes: For the fields of Heshbon languish, [and] the vine of Sibmah: the lords of the heathen have broken down the principal plants ${ }^{34}$ thereof, they are come [even] unto Jazer, they wandered [through] the wilderness: her branches are stretched out, they are gone over the sea (Isaiah 16: 8). In ampelographic descriptions ${ }^{35}$ there are

32 The coolness of the night is expressed through indexes. Very cool nights (marked as $\mathrm{IF}_{4}$ ), combined with optimal conditions from the normal ripening of grapes, enable topnotch quality, characterized by a better aroma and berries with more intense colours. $C f$. Nakalemić 2001: 130.

33 Grapevine can be easily propagated via canes, out of which seedlings can be made, which can be planted as cuttings or used for grafting. It is important that they be taken, for this purpose, during the period of winter (biological) stagnation.

34 While King James Bible doesn't specify the colour of the canes, it is a matter directly stated in the Serbian translation.

35 Modern ampelography is based on standards which can differ from descriptions given by Antique authors. That is why, under the section of canes colour (OIV, code 103), there are four characteristics listed. The one closest to red varieties with reddish-violet coloured branches / canes, but they are not that common. Therefore, the vines of Sibmah must have stood out in respect to the usual dark, yellow or brownish canes. On the Balkans peninsula, there were vineyards with canes in shades of red ever since the old times. Ružica, prokupac and skadarka; all these are varieties originating from the Balkans (convarietas pontica, subconvarietas balcanica), which have this particular characteristic (Cindrić et al. 1994, 23, 169, 225, 226). Perhaps the closest ones to the original vine from Sibmah are varieties from the chasselas group (conculta Chasselas), who are known in Serbia under their term of endearment-plemenke. Naturally, we cannot confirm the existence of chasselas in the verses of the Bible, however, aside from the similar canes colour, they have in common the fact that these are both very old varieties, originating from the Near East. According to their ecological-geographic attribution, they belong to convarietas orientalis, subconvarietas caspica, provarietes aminea, originating from the basin of the Caspian Sea (Cindrić et al. 1994: 23, 259). We learn from the verses that the vine of Sibmah spread spontaneously from Jazer all the way to the sea, most probably the Dead Sea. ${ }^{36}$ Spontaneous spreading, without any interventions of men, would have been conducted, logically, with seeds being transported by animals which were attracted by its sweet fruits.

A poetical description of clusters can be seen in the Song of Songs: now also thy breasts shall be as clusters of the vine (Song of Songs 7: 8). Comparing berries or clusters with breasts is not uncommon in the history of winegrowing. The same influence can be seen with Antique authors who named one variety Bumast (Columella 1745: 108). According to Varro, it was named thus because of the remarkable similarity of its clusters with cow udder, in Latin bumamma (Res rusticae, Wikisource.org). In house gardens of Serbia, a variety called popularly goat's tits has been cultivated for

is reddish-violet (OIV 2001).

36 The Dead Sea is at the distance of ca $25 \mathrm{~km}$ from the Antique city of Jazer. 
a very long time. It was named thus because of its distinctive berries. Aside from this, the comparison from the verses probably went in the direction of the size of clusters, a property which is the first one to define a variety of grapevine, along with the colour of the berries. In the Antiquity, they had already known of varieties with sparse clusters. The Book of Job compares a wicked man with a grapevine casting off unripe fruit. He shall shake off his unripe grape as the vine, and shall cast off his flower as the olive (Job 15: 33). Sparseness is precisely an occurrence when the vine, because of a lower level of pollination, fails to create berries, which thus either never form or fall off early, making the clusters straggling, sparse.

The importance of various varieties of grapevine, but other cultivated crops as well, enticed the cultivators to begin, since the early period of cultivation of plants, with their selection. Selection was performed, in a conscious or unconscious manner, by farmers in medieval Serbia as well. In the Gospel of Matthew, the Bible explicitly says: Do men gather grapes of thorns, or figs of thistles? (Matthew 7: 16). A good tree cannot bring forth evil fruit, neither [can] a corrupt tree bring forth good fruit. Every tree that bringeth not forth good fruit is hewn down, and cast into the fire (Matthew 7: 18, 7: 19). This form of selection is called massive negative selection, and it is easily put in action by removing those species which don't meet the needs of husbandmen. We do not know if trees with bad qualities were burned during the Middle Ages, but they were certainly omitted when branches for grafting were taken (or canes, or other vegetative material for obtaining seedlings). Bearing witness of the existence of a conscious choice of grapevine varieties during the Middle Ages is the old Serbian variety skadarka. Rumanian ampelographist Cosme assumed that it had arrived into the area of the Pannonian valley during the migration of the Serbs in the $17^{\text {th }}$ and the $18^{\text {th }}$ century (Cindric et al. 1994: 227). The fact that the people took canes of this variety, along with personal items and holy relics, into the unknown and a new life, speaks enough of their value. Properties required from grapevines and their fruit varied as much as the characters of people who tended them. It is safe to assume that fertility and appealing taste of the fruit were desirable qualities during the entire period of selection of this noble plant. We will conclude the confirmation of the quality estimation of different varieties of fruit and grapevine by medieval winegrowers with these words: Wherefore by their fruits ye shall know them (Matthew 7: 20).

Harvest represents the pivotal period of every winegrowing season. The Bible contains verses which provide us with approximate harvest time: And your threshing shall reach unto the vintage, and the vintage shall reach unto the sowing time (Leviticus 26: 5). Harvests which begin with threshing and end with the beginning of sowing time tell us that different varieties were cultivated in vineyards, with different ripening time. On the basis of the time of harvesting and sowing crops mentioned in the Bible, we cannot determine the optimal harvest time. ${ }^{37}$ Whenever it was that winegrowers picked grapes, they had to pick them only after they ripened. As verses from the Book of the Prophet Jeremiah say: every man that eateth the sour grape, his teeth shall be set on edge (Jeremiah 31: 30). Article 48 of the law of the tribe Paštrović also stipulates that only ripe grapes should be picked: ${ }^{38}$ He who should start picking grapes before the Nativity, ${ }^{39}$ let his grapes be given to the poor from the village, and his wine be drunk (Новаковић 1912: 109). Chapter 96 of the Statute of Budva strictly stresses the importance of timely harvest: On forbidding to press charges

37 It is not by chance that the Bible lists numerous types of grain. Starting with barley, which was reaped first, wheat, flax, millet etc. were harvested from the fields. They all have different times of sowing and reaping, especially when we take into consideration the difference between summer and winter crops.

38 The Statute of the župa of Grbalj near Budva and the tribe Paštrović. $C f$. Новаковић 1912: 104-105.

39 The Nativity of the Blessed Virgin Mary is celebrated on the $21^{\text {st }}$ of September according to the Julian calendar, i.e. on the $5^{\text {th }}$ of October according to the Gregorian calendar, which was in use at the time when this law was written. 
during harvest and vintage. We forbid that any of our citizens press charges against another during the time of harvest, i.e. from Saint Vito's Day up to Saint Elijah's day, and during the time of vintage, i.e. From Saint Mary's day in August up until Saint Michael's Day in September (Средњовековни статут Будве 1988: 36). The period between these two feasts (the $4^{\text {th }}$ of August - the $19^{\text {th }}$ of September, according to the Gregorian calendar) was the optimal time for obtaining high-quality vintage from the winegrowing areas near Budva, hence, no hindrances were allowed in those days.

It is interesting to note that numerous verses from the Bible demand that winegrowers shouldn't pick all the grapes from the vineyard, but instead leave some for the poor, travellers, birds and various beasts. One of them says: neither shalt thou gather [every] grape of thy vineyard; thou shalt leave them for the poor and stranger: I [am] the LORD your God (Leviticus 19: 10). Judging by these verses, during the harvesting of grapes, not all of it was taken from the vineyards. The ones from sprouts, which weren't ripe enough, and the ones which fell on the ground, for being too ripe, or had another problem, were left behind. Jagurida ${ }^{40}$ and grapes which have fallen to the ground significantly differ from those of top-notch quality. Harvesting time, as well as the attention dedicated to the quality of grapes tells us that medieval winemakers held firmly onto the truth that wine is made in the vineyard. Only completely ripe and hygienically clean grapes are good enough to end up in wine.

We don't know which percentage of grapes from vineyards ended up on the table, and which went on to wine presses during the Middle Ages. It is certain, however, that through processing, fermentation or drying, the nutritive value of grapes prolonged their expiration period. Hence, we see that in verses from the Bible winefats and wine presses went along with vineyards without fail: There was a certain householder, which planted a

40 Jagurida is a type of grapes which grows on barren canes. Since it was formed during the summer, it reaches technological ripeness in late autumn, if it manages to reach it at all before the autumn frost. vineyard, and hedged it round about, and digged a winepress in it, and built a tower, and let it out to husbandmen, and went into a far country (Matthew 21: 33). This way, we have confirmation that must and wine were considered as basic nutritional elements, whose quantity and quality made part of the general life standard. Sufficient is said by the verse in which grapevine declines the possibility of becoming the emperor of plants: And the vine said unto them, Should I leave my wine, which cheereth God and man, and go to be promoted over the trees? (Judges 9: 13). It is with these words that grapevine stresses the importance of its fruit and the impossible demand to deny it to the people, and leave them without it. Wine was an important nutriment on medieval monks' tables. Thus, Saint Sava prescribes its use in the Typikon of Hilandar - in everyday life (chapter 9) and during fasting periods (chapter 10). An extract from chapter 10, On Sacred fasts, the Grand fast and two small ones, in celebration of the Holy Apostles and Christ's birth, stipulates that: And on Saturday and Sunday during these sacred fasts, there shall be two meals: vegetable stew on oil and octopods. And the beverage (wine) should be the usual large measure. Thus you shall have (...) and on Tuesdays and Thursdays, let two different meals be brought before you, but not both of them with oil, but just one. And when wine is measured, small measure should be used, which is one half of the large one. And on other days: that is to say, Monday, Wednesday and Friday, no stewed meal and no wine shall be taken, but only lentils prepared with water and some fruit, and water beverage with cumin (Новаковић 1912: 353).

Numerous products made of grapes are mentioned in the Bible: He shall separate [himself] from wine and strong drink, and shall drink no vinegar of wine, or vinegar of strong drink, neither shall he drink any liquor of grapes, nor eat moist grapes, or dried (Numbers 6: 3). All the days of his separation shall he eat nothing that is made of the vine tree, from the kernels even to the husk (Numbers 6: 4) - almost all which can be used from grapes. Dried grapes (raisins) are 
a common mode of preservation of fresh grapes. They are mentioned in several verses: Stay me with flagons $^{41}$, comfort me with apples: for I [am] sick of love (Song of Songs 2: 5). Undoubtedly, monks' tables abounded with dried fruit during the periods of fasting in the Middle Ages; figs, pears, grapes. It is interesting to note that the verse quoted from Numbers 6:4 mentions eating unripe grapes. While talking about data found in the Archive of Dubrovnik, Blagojević enumerated frequent cases of stealing grapes in the middle of July (Благојевић 2004: 131). There are few varieties of grapevine which can reach full ripeness at this period of the year. Hence, even though unripe grapes didn't fulfil quality norms, they were still being stolen. Similarly to this, grape husk is, in fact, a nus-product created during the vinification of grapes, i.e. processes of stomping and pressing.

We can judge the quality of Biblical wine on the basis of its vinification as described by several verses. The first action taken to produce wine is pigeage - grape stomping: A [certain] man planted a vineyard, and set an hedge about [it,] and digged [a place for] the winefat (Mark 12: 1) Winefats and wine presses in vineyards make it possible for grapes to be processed rapidly, thus diminishing the possibility of flaws and damage in must and, later, wine, caused by oxidation and high temperature. Similarly to this, special objects were built in vineyards of medieval Serbia: wineries, wine cellars, meadows used for quick processing of grapes and optimal storage of wine. In The Charter of the Holy Archangels, Emperor Dušan says: I declare [that this place will represent] for this church of my Empire a granary, and winery, and the protector of the church instead of a tower (Новаковић 1912: 683). Grapes were stomped by feet in presses: the treaders shall tread out no wine in [their] presses (Isaiah 16: 10). In the following verse, we see a description of an intense fermentation: For in the hand of the LORD [there is] a cup, and the wine is red; it is full

41 In the Serbian translation, instead of flagons, we have dry grapes; however, the Russian translation we used also mentions wine, not dry grapes. of mixture ${ }^{42}$; and he poureth out of the same: but the dregs thereof (Psalms 75: 8). Once the fermentation would be finished, the wine was either poured out or left on the lees. Moab hath been at ease from his youth, and he hath settled on his lees, and hath not been emptied from vessel to vessel, neither ... therefore his taste remained in him, and his scent is not changed (Jeremiah 48: 11). The Bible gives a faithful description of technological processes linked to wine production. Depending on whether the wine was poured out immediately or left to age on the lees for a while, different results are obtained. During the aging on the lees, wine components are released into it, yeast et al. Zoecklein writes that those can have a positive impact on the increase of phenol, the quality of texture, richness of aroma and stability of wine - its durability (Zoecklein 2012). The intensity of colour in red wine is slightly lessened with the absorption of yeast from the lees, making it turn paler: Look not thou upon the wine when it is red (Proverbs 23:31). White wine, on the other hand, after remaining on the lees, becomes golden-yellow due to slight oxidation.

Two terms provide a clear distinction between how old the wine served on tables was. In the Bible, we find verses mentioning new wine and old wine. New wine can be understood in two senses: as must - freshly crushed grape juice, and as wine which only just finished fermenting. It is definitely must when Isaiah writes: As the new wine is found in the cluster (Isaiah 65: 8) or in the dream of the Cupbearer: And Pharaoh's cup [was] in my hand: and I took the grapes, and pressed them into Pharaoh's cup (Genesis 40: 11). Contrary to that, new wine, only just separated from the lees, can be seen in the following verse: No man also having drunk old [wine] straightway desireth new: for he saith, The old is better (Luke 5: 39). Old wine had a higher value in the Antiquity. Thus, we may see the following verses: And no man putteth new wine into old bottles; else the new wine will burst the

42 In the Serbian translation, the wine in question is described as foaming. In this case, however, the Russian translation coincides with the Serbian. 
bottles, and be spilled, and the bottles shall perish. But new wine must be put into new bottles; and both are preserved. (Luke 5: 37, 5: 38) ${ }^{43}$. Wineskins were made from the entire skin of the animal, in one piece, which was tanned. In time, the leather would become hard and lose elasticity. Therefore, one shouldn't put new wine into an old wineskin, because alcoholic fermentation would continue in it. Because of this fermentation, the hardened leather of an old wineskin would most probably crack. On the other hand, new wineskins had more elasticity and they could endure the pressure created by the release of carbon dioxide. Different quality categories were also defined for wine. It could have been sour, but also the best (in comparison to others). The already mentioned verse from the Song of Songs, aside from clusters, also compares wine to the beloved person: And the roof of thy mouth like the best wine (Song of Songs 7: $9)$. In several verses, wine with higher concentration of alcohol is mentioned: Thou hast shewed thy people hard things: thou hast made us to drink the wine of astonishment (Psalms 60: 3). A mention of sweet wine is provided by King James Version: ... and the mountains shall drop sweet wine, and all the hills shall melt ${ }^{44}$ (Amos 9: 13). High alcohol level or larger amounts of sugar which remained in the wine could have been the consequence of additions of some sort or using grapes with higher sugar concentration in the must. Both practices have been known ever since the Antiquity, and they have continued up to today. In the middle of the $14^{\text {th }}$ century, it was forbidden to serve wine with the addition of honey (molza, mellatum) from continental parts of Serbia in taverns of city municipalities at the Adriatic (Čremošnik 1933: 25).

Finally, the Bible offers us a description of exotic cultivation of vineyards, orchards and fields: Six years thou shalt sow thy field, and six years thou shalt prune thy vineyard, and gather in the

43 Again, it should be noted that instead of the word bottle, word wineskin is used, more appropriately, in the Serbian translation.

44 In the Serbian translation, literally: From mountains grape juice shall drop, and all the hills shall melt. fruit thereof; But in the seventh year shall be a sabbath of rest unto the land, a sabbath for the LORD: thou shalt neither sow thy field, nor prune thy vineyard. That which groweth of its own accord of thy harvest thou shalt not reap, neither gather the grapes of thy vine undressed: [for] it is a year of rest unto the land (Leviticus 25: 3, 25: 4, 25: 5). The described manner of tending a vineyards has no parallel in any of the winegrowing techniques that the author is familiar with. It is possible that it is mentioned in the Bible only because of its symbolic value, but it is worth considering what would occur if a vineyards is not tended during every vegetation cycle. We know that a vineyard can be brought into the regular state of care, with a higher or smaller degree of success, even after several years of neglecting; if pruning, hoeing is omitted etc. One of the necessary conditions for that is that, during that pause, no severe epidemics of dangerous fungal diseases should occur, such as powdery mildew (Uncinula necator), grey mould on the grapes (Botryits cinerea) and especially downy mildew (Plasmopara viticola), which could lead to the drying of the vines. Judging by the verses from the Bible, but also the information from the Middle Ages, or, to be more precise, the lack thereof, ${ }^{45}$ those listed diseases didn't represent a significant problem. According to the verses from the Bible, the only problems in vineyards, aside from the human factor, were caused by worms, foxes and other earthly creatures: Take us the foxes, the little foxes, that spoil the vines: for our vines [have] tender grapes ${ }^{46}$ (Songs Of Songs 2: 15).

Leaving the vineyard to take care of itself

45 Any epidemics of the mentioned diseases would certainly have been noted in history, for, unless they are brought under control, they cause an almost complete devastation of winegrowing terrains on which they occur. An example of this can be found in the middle of the $19^{\text {th }}$ century, when their occurrence in European vineyards lead to a permanent change in the manner in which winemakers tend their vineyards.

46 While the Serbian translation talks about grapevines in bloom, King James Version talks about tender grapes (Song of Songs, 2:15). Those tender grapes can be taken as a description of the phenophase of berries, which follows the bloom. 
leads to auto-regulation of the yields and vegetative parts of the grapevine, which leads to some sort of equilibrium being achieved, where the vine frees itself from the excess of fruit by letting it fall or of the surplus of green mass by letting it dry. However, when considering a vineyard left without any human intervention, we wouldn't be able to speak of winegrowing in the true sense of the word. Omitting to prune diminishes the activation of nodes, which, in a way, preserves the vegetative potential (strength) of the vine. However, even with these explications of the consequences of applying this agro-technical measure, we still don't have enough arguments on the basis of which we could deduce reliable conclusions.

\section{$* * *$}

Arheologija i prirodne nauke (Archaeology and Science) is an Open Access Journal. All articles can be downloaded free of charge and used in accordance with the licence Creative Commons - Attribution-NonCommercial-NoDerivs 3.0 Serbia (https://creativecommons.org/licenses/bync-nd/3.0/rs/.

Časopis Arheologija i prirodne nauke je dostupan u režimu otvorenog pristupa. Članci objavljeni u časopisu mogu se besplatno preuzeti sa sajta i koristiti u skladu sa licencom Creative Commons - Autorstvo-Nekomercijalno-Bez prerada 3.0 Srbija (https://creativecommons.org/licenses/bync-nd/3.0/rs/.

\section{BIBLIOGRAPHY}

\section{Aversano et al. 2017.}

Dating the beginning of the Roman viticultural model in the Western Mediterranean: The case study of Chianti (Central Italy). PLOS one. //www. ncbi.nlm.nih.gov/pmc/articles/PMC5687709/. (17th October 2018).

Библия Книги Священного Писания Ветхого и Нового Завета, Синодальный Текст Третье издание. Издательства Московской
Патриархии. 2007. //www.sdhs.co.uk/wp-content/uploads/2012/03/SYNODAL.pdf. (30th November 2017).

(Bibliia Knigi Sviashchennogo Pisaniîa Vethogo i Novogo Zaveta, Sinodal'n'iĭ Tekst - Tret'e izdanie. Izdatel'stva Moskovskoĭ Patriarhii. 2007. //www.sdhs.co.uk/wp-content/uploads/2012/03/ SYNODAL.pdf. (30th November 2017).

\section{Благојевић, М. 2004}

Земьорадња у средњовековној Србији, Београд: ЈП Службени лист СЦГ.

(Blagojević, M. 2004

Zemljoradnja u srednjovekovnoj Srbiji, Beograd: JP Službeni list SCG.)

\section{Благојевић, М. 2007}

Земььораднички закон: средњовековни рукопис, Београд: САНУ.

(Blagojević, M. 2007

Zemljoradnički zakon: srednjovekovni rukopis, Beograd: SANU.)

\section{Бубало, Ђ. 2010}

Душанов законик, Београд: Завод за уџбенике, Службени Гласник.

(Bubalo, Đ. 2010

Dušanov zakonik, Beograd: Zavod za udžbenike, Službeni Glasnik.)

\section{Geoponika 1805}

ГЕЛПОНИКА - agricutural pursuits vol. I, transleted from greek by the Rev. T. Owen, M. A. 1805. London: Printed for the author, By W. Spilsbury. (Geoponika 1805

GEOPPONIKA - agricutural pursuits vol. I, transleted from greek by the Rev. T. Owen, M. A. 1805. London: Printed for the author, By W. Spilsbury.)

\section{Zoecklein, B. 2012}

The Nature of Wine Lees \& Lees Management Considerations. New world winemakercom. http://www.newworldwinemaker.com/article/understanding-wine-lees/. (6th October 2018). 
Јиречек, К. 1978

Историја Срба II (културна историја), Београд: Слово љубве.

(Jireček, K. 1978

Istorija Srba II (kulturna istorija), Beograd: Slovo ljubve.)

Ковачевић, Љ. 1890

Светостефанска хрисовуља, Споменик СКА, IV: 1-11.

(Kovačević, LJ. 1890

Svetostefanska hrisovulja, Spomenik SKA, IV: 1-11.)

\section{Ковијанић, Р. 1962}

Вита Которанин неимар Дечана, Београд: Нолит.

(Kovijanić, R. 1962

Vita Kotoranin neimar Dečana, Beograd: Nolit.)

\section{Марјановић-Душанић, С. 2003}

Хрисовуља краља Душана о даровању манастиpa Св. Николе Мрачког у Орехову манастиру Хиландару, у Старом српском архиву, ур. Раде Михаљчић, Београд: Филозофски факултет Београд, Филозофски факултет у Бања Луци: 55-68. (Marjanović-Dušanić, S. 2003

Hrisovulja kralja Dušana o darovanju manastira Sv. Nikole Mračkog u Orehovu manastiru Hilandaru, u Starom srpskom arhivu, ur. Rade Mihaljčić, Beograd: Filozofski fakultet Beograd, Filozofski fakultet u Banja Luci: 55-68)

\section{C. Pell et al. 2007}

Updated world map of the Koppen-Geiger climate classification. Hydrology and Earth System Sciences. https://www.hydrol-earth-syst-sci.net/11/1633/2007/ hess-11-1633-2007.pdf. (3 ${ }^{\text {th }}$ October, 2018).

\section{Nakalemić, A. J. 2001}

Opšte vinogradarstvo, Beograd: Univerzitet $\mathrm{u}$ Beogradu, Poljoprivredni fakultet.

Новаковић, С. 1912
Законски споменищи српских држава средњег века, Београд: Српска краљевска академија. (Novaković, S. 1912

Zakonski spomenici srpskih država srednjeg veka, Beograd: Srpska kraljevska akademija.)

\section{OIV 2001}

OIV descriptor list for grape varietes and Vitis species. http://www.vivc.de/docs/Code_descripteurs_2ed_EN.pdf. (4 $4^{\text {th }}$ June 2017).

\section{Орбин, М. 1968}

Краљевство Словена. Београд. Српска књижевна задруга. https://istorijabl.weebly. com/uploads/9/8/3/5/9835868/mavro_orbini_ kraljevstvo_slavena.pdf. (16th April, 2018).

(Orbin, M. 1968

Kraljevstvo Slovena. Beograd. Srpska književna zadruga. https://istorijabl.weebly.com/uploads/9/8/3/5/9835868/mavro_orbini_kraljevstvo_slavena.pdf. (16th April, 2018).)

\section{Радојичић, Н. 1962}

Закон о рудницима деспота Стефана Лазаревића, Београд: Научно дело.

(Radojičić, N. 1962

Zakon o rudnicima despota Stefana Lazarevića, Beograd: Naučno delo.)

Свето писмо или Библија Старог и Новог завета. Београд: Метафизика. http://revelationtoday. ucoz.com/Biblija_nsp.pdf. (24th Septembr 2017). (Sveto pismo ili Biblija Starog i Novog zaveta. Beograd: Metafizika. http://revelationtoday.ucoz. com/Biblija_nsp.pdf. (24th Septembr 2017).)

\section{Средњовековни статут Будве 1988}

Средњовековни статут Будве. 1988. Будва: Историјски архив Будва. http://montenegrina. net/pdf/Statut\%20Budve.pdf. (10th April 2017).

(Srednjovekovni statut Budve 1988

Srednjovekovni statut Budve. 1988. Budva: Istorijski arhiv Budva. http://montenegrina.net/pdf/ Statut\%20Budve.pdf. (10th April 2017).) 
Toussaint-Samat, M. 2009

A History of Food, Chichester, West Sussex: Blackwell publishing Ltd.

The King James Version of the Holy Bible. http://www. av-1611.com/KJBIBLE.pdf. (29th November 2017).

\section{Ћирић,Ђ. 2017}

Агротехника у виноградима средњовековне Србије. Дипломски рад, Пољопривредни факултетет, Универзитет у Београду.

(Ćirić,Đ. 2017

Agrotehnika u vinogradima srednjovekovne Srbije. Diplomski rad, Poljoprivredni fakultetet, Univerzitet u Beogradu.)

\section{Ćorović, V. 2001}

Istorija srpskog naroda I. Beograd: „Glas srpski”, Banja Luka. "Ars Libri”, Beograd. https://www.rastko.rs/rastko/bl/istorija/corovic/ istorija/index_1.html. (22nd October 2018).

\section{Hrvatska enciklopedija 2018}

Hrvatska enciklopedija, mrežno izdanje, Zagreb: Leksikografski zavod Miroslav Krleža. http:// www.enciklopedija.hr/natuknica.aspx?id=13585. (28th October 2018).

\section{Cindrić et al. 1994}

Sorte vinove loze, Novi Sad: Prometej.

\section{Columella 1745}

Junius Moderatus Columella Of Husbandry, In Twelve Books: and His Book Concerning Trees. Originally published in (London: 1745).

https://play.google.com/books/reader?id=qcNbAAAAMAAJ\&printsec $=$ frontcover\&source $=\mathrm{gbs}$ atb_hover\&pg=GBS.PA166.(7th October 2018).

\section{Čremošnik, G. 1933}

Vinogradarstvo $i$ vino $u$ srednjovekovnoj Dalmaciji, 15-38. Sarajevo: Glasnik Zemaljskog muzeja u Sarajevu.

Wikisource. https://en.wikisource.org/wiki/Res Rusticae_(Country_Matters). (1st October 2018).

\section{REZIME}

SVETO PISMO KAO IZVOR PODATAKA O SREDNJOVEKOVNOM VINODELSTVU U SRBIJI

\section{KLJUČNE REČI: SVETO PISMO, VINODELST- VO, SREDNJI VEK, SRBIJA, PISANI IZVORI.}

Upoređivanjem dostupnih izvora vidi se da je Sveto pismo direktno i indirektno uticalo na vinodelstvo srednjovekovne Srbije. Njegovi stihovi su predstavljali norme, propise i savete primenjivane u srednjovekovnim zakonicima, statutima i još direktnije sproveđeni u vinogradarskoj i vinarskoj praksi. U to nas ne uveravaju samo pisani i oslikani izvori tog perioda već i logika poljoprivredne proizvodnje. Za neke stihove nema konkretnih dokaza već samo pretpostavke. Sveto pismo ne otkriva određene sorte koje su sađene u vinogradima srednjovekovne Srbije ili bolesti koje su činile probleme $u$ istim. Drugi stihovi su pak opšte poznati svakome ko se bavi negom vinove loze i vina. Okopavanje, rezidba, vino koje stoji na talogu, štetnost prekomernog ispijanja vina i drugi termini su bili vrlo bliski srednjovekovnom vinodelcu u Srbiji. Ovim radom se želi dokazati autentičnost reči iz Svetog pisma koji se odnose na vinovu lozu i vino kao i njihova interakcija sa srpskim srednjovekovnim vinodelstvom. Takođe u njemu su iznete potvrde vinogradarskih praksi koje su izvođene tokom srednjeg veka. Zanimljive su i prakse koje nisu potvrđene sa srednjovekovnim izvorima. Ostavljanje vinograda bez nege jednu vegetaciju verovatno nije bila voljna akcija vinodele, jer bi zbog toga bio kažnjen od strane crkve, vlastelina, vlasnika vinograda koji je uzeo u zakup. Iz svega navedenog reči Svetog pisma u saradnji sa drugim izvorima podataka o srednjovekovnom vinodelstvu i njihova eksperimentalna izvedba pomažu da se shvate mehanizami u kojima su negovani vinogradi i nastajalo vino srpske srednjovekovne države. 